\title{
TRASCENDIENDO FORMULACIONES TRINITARIAS: HACIA UNA TEORÍA CONCEPTUAL DE LOS ÓRGANOS CONSTITUCIONALES AUTÓNOMOS EN LA DIVISIÓN DE PODERES EN MÉXICO
}

\author{
MAURO ARTURO RIVERA LEÓN
}


SUMARIO:

1. LA DIVISIÓN DE PODERES COMO CONCEPTO CONSTITUCIONAL. 2. EVOLUCIÓN DE LA DIVISIÓN DE PODERES EN LA HISTORIA CONSTITUCIONAL MEXICANA. 2.1. La Constitución de Apatzingán como formulación rígida. 2.2. El nuevo federalismo en la Constitución de 1824. 2.3. Siete leyes y un guardián (1836): El Supremo Poder Conservador y la división de poderes. 2.4. La Constitución de 1857. 2.5. 100 años de división de poderes: La Constitución de 1917. 3. ÓRGANOS CONSTITUCIONALES AUTÓNOMOS Y DIVISIÓN DE PODERES. 3.1. El surgimiento del concepto de órganos constitucionales autónomos. 3.2. De confusiones y equívocos: El equivocado uso de la doctrina mexicana de García Pelayo. 3.3. La definición de la Suprema Corte. 4. HACIA UNA NUEVA DEFINICIÓN DE ÓRGANOS CONSTITUCIONALES AUTÓNOMOS. 4.1 ¿Órganos autónomos o constitucionalización de administraciones independientes u otras instituciones no mayoritarias? 4.2. El cariz de la constitucionalización. 4.3. Intento de definición y exclusiones. 5. CONCLUSIONES. 


\title{
TRASCENDIENDO FORMULACIONES TRINITARIAS: HACIA UNA TEORÍA CONCEPTUAL DE LOS ÓRGANOS CONSTITUCIONALES AUTÓNOMOS EN LA DIVISIÓN DE PODERES EN MÉXICO
}

\author{
MAURO ARTURO RIVERA LEÓN ${ }^{1}$
}

\section{LA DIVISIÓN DE PODERES COMO CONCEPTO CONSTITUCIONAL}

La división de poderes es un principio fundamental del constitucionalismo ${ }^{2}$. El pensamiento de Locke 3 , Hume, Montesquieu ${ }^{4}$ y Madison se ha consagrado con enorme nitidez en el constitucionalismo. En la actualidad, es usualmente aceptada una formulación trinitaria ${ }^{5}$ que divide al poder en ejecutivo, legislativo y judicial, impidien-

1 Profesor de derecho en la Universidad Iberoamericana. Prolongación Paseo de Reforma 880, Lomas de Santa Fe, México, C.P. 01219, Ciudad de México. Miembro del Sistema Nacional de Investigadores (SNI-I). @MauroArturo (Twitter). ORCID: 0000-0003-4964-7086. arturo.riverale@ gmail.com. Partes menores de la sección 1 y subsección 3.1 de este trabajo están basadas en secciones no publicadas de mi tesis doctoral.

2 Bellamy, R., "The political form of the constitution: separation of powers, rights and representative democracy», Political Studies, vol. 44, núm. 3, 1996, p. 436. Sobre el principio es clásico. VILE, M., Constitucionalismo y división de poderes, Madrid, CEPC, 2007. Varios autores han resaltado que la división de poderes contribuye significativamente a la tutela de derechos fundamentales: STARCK, C., «Logros de la cultura jurídica», Revista de Derecho Político, Madrid, núm. 87, mayo-agosto de 2013, p. 138 y SLAUghter, A., "A typology of transjudicial communication», University of Richmond Law Review, núm. 99, 1994, p. 135.

Locke, J., Two treatises of Government, Nueva York, Everyman's Library, 1924, p. 190.

4 Montesquieu, C., El espíritu de las Leyes, Madrid, Librería General Victoriano Suárez, 1906, p. 227. También el clásico análisis de D'Alembert, J., «Analyse de L'Esprit des Lois», en MontesQuieu, C., L'Esprit des Lois, París, Chez Sanson et Compagnie, 1784, p. 110.

5 La expresión «trinitaria» ha sido empleada ocasionalmente para designar a la formulación clásica de la tríada de poderes. García Pelayo, M., «La división de poderes y su control jurisdiccional», Revista 
do la reunión de dos de éstos en la misma persona o la unidad del legislativo en una persona y no un cuerpo colegiado. La naturaleza imperativa de este principio comúnmente se establece en todas las constituciones mediante un reconocimiento expreso o tácito.

El desarrollo constitucional ha hecho evolucionar un entendimiento rígido de la división de poderes. La propia Constitución norteamericana confiaba no tanto en la rígida separación de poderes, sino en una relación sustancial de controles entre quienes desempeñaban las funciones constitucionales (checks and balances ${ }^{6}$ ).

Una interpretación mecanicista de la división de poderes propuesta por Montesquieu $^{7}$ se torna complicada de sostener en regímenes parlamentarios por la relación entre parlamento y gobierno. Inclusive en el presidencialismo, la evolución constitucional ha dificultado sostener una concepción rígida a ultranza de la división de poderes cuando la función ejecutiva, legislativa y judicial no es ejercida en exclusiva por su poder preferente.

La proliferación de Tribunales Constitucionales en la posguerra ha evidenciado también la insuficiencia de las categorías clásicas de la tríada de poderes para el entendimiento de la realidad constitucional, situando a un importante actor de la vida institucional fuera de los tres poderes ${ }^{8}$. La terminología doctrinal ha reconocido esta evolución, proponiendo conceptos más adecuados a la realidad como la separación de funciones, distinción de funciones ${ }^{9}$ o la organización constitucional ${ }^{10}$. El entendimiento de la división de poderes se ha ajustado a la realidad constitucional ${ }^{11}$.

La verticalidad de la división de poderes contribuiría a la evolución del principio. El federalismo norteamericano dividió sucesivamente el poder entre Entidades Federativas y la federación. Federación y Entidades Federativas, compartirán los poderes clásicos basándose en recíprocos controles competenciales. La tónica del federalismo se ha trasladado inclusive a regímenes centralistas que han vivido bajo un progresivo proceso de tácita federalización.

de Derecho Político, Madrid, núm. 18-19, 1983, p. 15 y ss. Igualmente Ackerman, B., «The New Separation of Powers», Harvard Law Review, vol. 113, núm. 3, enero de 2000, pp. 668, 720, 721 y 725.

6 Madison, J., «The same subject continued, with the same view and concluded» (núm. 51), The federalist papers, Kramnick, I. (ed.), Londres, Penguin Classics, 1987, p. 319.

7 La cuestión no es pacífica en la doctrina. Sobre el debate respecto a un problemático entendimiento de Montesquieu: Claus, L., «Montesquieu's Mistakes and the True Meaning of Separation», Oxford Journal of Legal Studies, Oxford, vol. 25, 2005, pp. 419-451.

8 Kelsen, H., «Wesen und Entwicklung der Staatsgerichtsbarkeit», en Wer soll der Hüter der Verfassung sein?, Tübingen, Mohr Siebeck, 2008, pp. 23 y ss. García RocA, J., La experiencia de veinticinco años de Jurisdicción Constitucional en España, México, Porrúa, 2009. pp. 20 y 21.

9 Favorecida en Schmitт, C., Teoría de la Constitución, Madrid, Editorial Revista de Derecho Privado, 1934, p. 212. A su vez, el propio Kelsen defendía la distribución de funciones: KeLSEN, H., Teoría general del Estado y del derecho, México, UNAM, 1950, p. 286.

10 Cfr. Mortati, C., Studi sul potere costituente e sulla reforma costituzionale dello Stato, Milán, Giuffrè, 1972 , p. 685.

11 Véase FERnÁndez SARAsola, I., «La división de poderes en la historia constitucional española», Fundamentos, Madrid, núm. 5/2009, pp. 169-202. 
El diseño constitucional de diversos países se encargaría de plantear ulteriores encrucijadas al entendimiento rígido de la división de poderes. Diversas Constituciones dotan de autonomía a una serie de órganos, como se analizará posteriormente.

El principio de la división de poderes ha debido amoldar su entendimiento a la dinámica de partidos políticos. Si analizamos la historia del propio principio, encontraremos que estuvo moldeado por una concepción del parlamentarismo de corte individualista con mandato representativo. Inclusive para el presidencialismo, si el parlamento se concibió como un órgano deliberativo cuyos miembros se encontraban amparados bajo la prohibición de un mandato imperativo, la realidad se tornó problemática. La preeminencia de los partidos políticos frente al representante individual es una realidad tanto para modelos parlamentarios como para modelos presidenciales.

Por tanto, se ha planteado que la división de poderes debe ir acompasada a una división de partidos ${ }^{12}$, entendida ésta como el reconocimiento de las tensiones políticas de los órganos conformados de manera pluripartidista (el parlamento como órgano de órganos). Así, se ha considerado que debe insertarse a la clásica división horizontal-vertical, una dinámica de partidos, caracterizada por la oposición minoría-mayoría. De tal suerte, existe un continuum conformado por el proceso electivo del órgano y su funcionamiento: el funcionamiento y el método electivo no pueden ser más que dos momentos interrelacionados ${ }^{13}$. Bajo esta óptica, es posible señalar que un parlamentario se identifica más con el partido político que lo ha postulado (en el caso de elecciones uninominales) o incluido en la lista (en el caso de la lista plurinominal) que con el órgano del cual es integrante. La práctica política demuestra que predecir el comportamiento o percepción de un actor político en torno a una decisión, usualmente, requiere conocer el partido político al que pertenece y no tanto su condición de diputado o senador, los principios o la circunscripción por la que fue electo. A pesar de que la identificación se produce mayormente en el parlamentarismo (donde la mayoría parlamentaria ha formado gobierno), en el presidencialismo no es poco frecuente que la mayoría parlamentaria sea del partido que ha obtenido el poder ejecutivo, con lo cual puede producirse una confusión de la división de poderes. Frecuentemente, esta misma mayoría tiende a tolerar conductas por parte del ejecutivo que tendrían un tratamiento en tónica diversa por partidos de oposición.

Los mecanismos de tutela de la división de poderes han evolucionado de forma conjunta al principio mismo. Durante mucho tiempo, fue frecuente que uno de los

12 Davison, L. y Pildes, R., «Separation of parties not powers», Harvard Public Law Working Papers, USA, núm. 131, 2006, p. 17. Anteriormente, la tradición parlamentaria europea ya analizaba los conceptos de oposición y minorías parlamentarias. A modo de precedente, DE VergotTini, G., Lo «shadow cabinet»: Saggio comparativo sul rilievo costituzionale dell'opposizione nel regime parlamentare britannico, Milán, Giuffré, 1973, pp. 1-48 y más recientemente DE VERGotTini, G., «La forma de gobierno de oposición garantizada», Revista de Estudios Políticos, Madrid, núm. 9, 1979, pp. 5-42.

13 Presno Linera, M., «Pluralismo de partidos, no separación de poderes», Fundamentos, Madrid, 5/2009, p. 276 y ss. 
poderes directamente prevaleciera sobre los demás y solventara las disputas desde una posición de preeminencia ${ }^{14}$.

La búsqueda de mecanismos jurisdiccionales nos ofrece un nítido precedente en el Staatsgerichtshof de la Constitución de Weimar que en su artículo 108 establecía un tribunal estatal que dirimía controversias sobre la Constitución y la constitucionalidad de una acción gubernamental ${ }^{15}$. Esta primera aproximación a la solución de controversias constitucionales resultó fundamental y se ha mantenido en la evolución constitucional alemana ${ }^{16}$. La idea principal sobre la que oscila la Staatsgerichtsbarkeit es la judicialización de los conflictos políticos ${ }^{17}$.

Las repercusiones del modelo alemán fueron notables. Inclusive, el proceso constituyente austriaco que culminaría en 1920, influenciado fuertemente por el modelo kelseniano de control jurisdiccional abstracto, discutió erigir al Verfassungsgerichtshof como un árbitro de conflictos competenciales ${ }^{18}$ o un tribunal central de conflictos ${ }^{19}$.

Con el auge de la jurisdicción constitucional en la posguerra, las distintas constituciones incorporarían estas competencias a sus tribunales constitucionales. Así, el reconocimiento de que las cláusulas sobre la división de poderes son cláusulas jurídicas es el aspecto más relevante de la judicialización de los conflictos entre órganos ${ }^{20}$. La defensa del régimen competencial se tornó en una necesidad del estado constitucional ante la indisponibilidad de las competencias reguladas por el constituyente ${ }^{21}$.

En el caso mexicano la división de poderes se tutela por la controversia constitucional establecida en el artículo 105 constitucional e introducida a raíz de la reforma constitucional de 1994 que buscó transformar a la Suprema Corte mexicana en un Tribunal Constitucional material ${ }^{22}$. En las siguientes secciones se analizará la evolución de la división de poderes en México para mostrar cómo sólo el constitucionalismo

14 Gómez Montoro, A., El conflicto entre órganos constitucionales, Madrid, Centro de Estudios Constitucionales, 1992, p. 35. MoyA es un buen ejemplo de la concepción política. Ya en 1890 argumentaba que los conflictos entre poderes del Estado debía resolverlos el monarca en su posición de «Poder Moderado» aconsejado por asesores que conocieran la opinión pública. Véase MoyA, C., El conflicto entre poderes del Estado, Madrid, El Liberal, 1890, pp. 220-221.

15 RiTTER, K., Die verfassungsrechtlichen Streitigkeiten vor dem Staatsgerichtshof für das Deutsche Reich, Heildelberg, Carl Winters Universitätsbuchhandlung, 1930, p. 14.

16 Schade, P., Grundgesetz mit Kommentirung, Walhalla, Rechtshilfen, 2009, p. 254 y ss.

17 Cruz Villalón, P., La formación del sistema europeo de control de constitucionalidad, Madrid, Centro de Estudios Constitucionales, 1987, p. 128.

18 En este sentido, ÖHLInger, T., «Hans Kelsen y el Derecho constitucional federal austriaco: una retrospectiva crítica», Revista Iberoamericana de Derecho Procesal Constitucional, México, núm. 5, 2006, p. 219.

19 Kelsen, H., La garantía jurisdiccional de la Constitución, Op. Cit., p. 69.

20 Aragón Reyes, M., Estudios de Derecho Constitucional, Madrid, CEPC, 2009, p. 317.

21 García Roca, J., «Una teoría de la sentencia en el conflicto constitucional de competencia entre entes territoriales», en AA.VV., La Sentencia en los conflictos constitucionales de competencia, Madrid, CEPC, 1998, p. 37.

22 In toto Rivera León, M., Las Puertas de la Corte, México, Porrúa, 2016. 
de 1836 y de 1917 (en sus reformas posteriores a 1993) cuestionó la tríada clásica de poderes.

\section{EVOLUCIÓN DE LA DIVISIÓN DE PODERES EN LA HISTORIA CONSTITUCIONAL MEXICANA}

\subsection{La Constitución de Apatzingán como formulación rígida}

Aunque la Constitución de Cádiz es la primera Constitución aplicada en el territorio nacional, la Constitución de Apatzingán es el primer texto elaborado en Méxi$\mathrm{Co}^{23}$. No obstante la autoría del texto siga siendo objeto de debate ${ }^{24}$, éste presenta una clara influencia de la revolución francesa, la Constitución de Cádiz y de las ideas propias del liberalismo, además de las ideas de los Elementos Constitucionales de López Rayón y los Sentimientos de la Nación de Morelos.

El artículo 11 establecía las atribuciones de la soberanía que se traducen en las funciones del Estado, a saber, la facultad de dictar leyes, la facultad de hacerlas ejecutar y la facultad de aplicarlas a casos particulares. Inmediatamente (art. 12), procedía a designar a los tres poderes correspondientes a tales funciones (legislativo, ejecutivo y judicial) y la prohibición expresa de que tales poderes se ejerzan por una sola persona o corporación.

En contraste con el constitucionalismo de Estados Unidos, en Apatzingán, probablemente por influencia Gaditana ${ }^{25}$ se empleó una formulación rígida de la división de poderes de preeminencia legislativa. El Supremo Congreso tenía facultad (art. 103) de elegir a los individuos que conformarían el Supremo Gobierno y al Supremo Tribunal de Justicia. Los propios diputados y miembros del Tribunal de Justicia se encontraban impedidos de ser electos miembros del Gobierno ${ }^{26}$.

Esta separación rígida hubiese tornado la relación entre Parlamento y Gobierno bastante difícil. No existían mecanismos de interconexión, ni se menciona la comparecencia al Parlamento de miembros del Gobierno y ciertamente la alternación por cuatrimestres de la Presidencia del Gobierno habría producido un Ejecutivo débil supeditado a las inestabilidades de cortos cambios de liderazgo y un Congreso con grandes poderes.

23 Lamonte, E. «La Constitución de Apatzingán: Primera Carta Magna mexicana», en AA.VV., Congreso Internacional sobre el 75 Aniversario de la Promulgación de la Constitución Política de los Estados Unidos Mexicanos, México, UNAM, 1993, p. 418 y BurgoA, I., Derecho Constitucional Mexicano, México, Porrúa, 1973 , p. 92.

24 Macías, A., «Los autores de la Constitución de Apatzingán», Historia Mexicana, vol. 20, núm. 4, 1971, p. 512 .

25 Breña, R., «La Constitución de Cádiz y la Nueva España: cumplimientos e incumplimientos», Historia Constitucional vol. 13, 2012, p. 373.

26 Éste es uno de los elementos de la definición pura de la doctrina de la separación de poderes. Así Vile, M., Op. Cit., p. 14. 


\subsection{El nuevo federalismo en la Constitución de 1824}

La Constitución de 1824 consagró nuevamente una fórmula tripartita de la división del poder. En su título segundo se declara que «Se divide el Supremo Poder de la Federación para su ejercicio, en legislativo, ejecutivo y judicial». La formulación es típica de los textos constitucionales de la época. Mantiene la unidad conceptual ${ }^{27}$ y la división se realiza únicamente en la ejecución del poder. En herencia de la Constitución de Apatzingán, aún empleaba el orden en que se conceptualizaba al poder legislativo como primus inter partes. A pesar de ello, el hecho de que la Constitución se abstuviera de consagrar el ejercicio soberano exclusivamente por parte del poder legislativo fue una innovación per $\mathrm{se}^{28}$.

Esta Constitución adopta por vez primera el federalismo en México. Como han apuntado varios autores ${ }^{29}$, la Constitución de 1824 no se basó exclusivamente en el diseño de la Constitución norteamericana ${ }^{30}$, sino mantuvo una marcada influencia gaditana.

El propio título II estableció que la nación mexicana adoptaba para su gobierno la forma de «república representativa popular federal» y procedía a desglosar las partes de la federación. Ello implicaba que el título II contenía la totalidad del esquema de división de poderes tanto en su forma horizontal como vertical. En cuanto al poder legislativo, la Constitución de 1824 adoptó el bicameralismo por vez primera, ante el influjo del constitucionalismo norteamericano, dividiendo al Congreso de la Unión en Cámara de Diputados y Cámara de Senadores.

El diseño del Poder Ejecutivo en la Constitución era problemático. En primer lugar, la elección no era popular, sino realizada por las legislaturas de los Estados. Se buscaba minar su legitimidad directa para evitar una concentración del poder o tendencias tiránicas. En segundo término, se adoptó un modelo de presidencia y vicepresidencia y se designaba al vicepresidente como sustituto nato ante las faltas absolutas del ejecutivo. El problema orgánico de diseño radicaba en que el propio diseño constitucional (artículos 81-86) establecía que la vicepresidencia recaería en el segundo lugar en votación, con lo cual situaba en el Poder Ejecutivo a enemigos políticos natos con intereses encontrados: un modelo calificado de «disparate constitucional» ${ }^{31}$. La Constitución de 1824 sufriría una crisis política fuerte que culminaría con su caída en 1835.

27 GonzÁlez, L., «El paréntesis de Santa Anna», en Cosío Villegas, D. et al, Historia Mínima de México, México, Colegio de México, 2003, p. 100.

28 Ello ha sido notado por Ávila, especialmente en la comparativa con Estados como Puebla que insistieron en consagrar la superioridad legislativa (1808-1824). ÁviLA, A., En nombre de la Nación: La formación del Gobierno representativo en México, México, Taurus/CIDE, 1999, p. 279.

29 Andrews, C., «Una alternativa para el Modelo Gaditano: La presencia del Pensamiento Constitucional Anglosajón en México (1821-1830)», en LunA, A. y Mijangos, P. et al, De Cádiz al siglo XxI: Doscientos años de constitucionalismo en México e Hispanoamérica, México, Taurus, 2012, p. 67.

30 Chust, M. y Frasquet, I., «Orígenes federales del republicanismo en México, 1810-1824», Mexican Studies/Estudios Mexicanos, vol. 24, núm. 2, verano de 2008, p. 364.

31 Pantoja, D., «El diseño constitucional del Ejecutivo en México y sus problemas», Foro Internacional, México, vol. XXXVIII, abril-septiembre de 1998, p. 255. 


\subsection{Siete leyes y un guardián: El Supremo Poder Conservador y la división de poderes}

Las Siete Leyes Constitucionales de 1836 resultó un texto innovador ${ }^{32}$ dada su originalidad por la ruptura de la tríada clásica de la división de poderes con la inclusión de un cuarto poder: el denominado Supremo Poder Conservador. Esta figura ha sido enjuiciada con severidad por la doctrina mexicana ${ }^{33}$, quizá nublada por la carga del resultado histórico ${ }^{34}$.

El Supremo Poder Conservador era un órgano compuesto por cinco individuos de renovación escalonada en períodos bianuales mediante un complejo sistema de listas. Sus competencias resultan de gran interés. El Poder Conservador podía declarar la nulidad de una ley por contravenir a la Constitución, declarar la nulidad de actos del poder ejecutivo por contravención a la Constitución, declarar la nulidad de actos de la Suprema Corte en caso de usurpación de facultades, declarar la incapacidad física o moral del Presidente de la República, suspender a la Alta Corte de Justicia o al Congreso, restablecer a cualquiera de los tres poderes cuando se hubiesen disuelto revolucionariamente, declarar la voluntad de la nación, dar o negar la sanción a las reformas constitucionales, calificar la elección senatorial, entre otras.

El Supremo Poder Conservador se nutrió de las influencias del Poder Moderador de Constant ${ }^{35}$ y del Jury constitutionnaire de Sieyès ${ }^{36}$ sin ser reproducción fiel de ninguno $^{37}$. Sus competencias podría arrojarnos paralelismos con el Tribunal Constitucional que Kelsen propondría muchos años después ${ }^{38}$. A pesar de que algunas competencias son coincidentes con las de un Tribunal Constitucional, lo distingue la naturaleza política de sus miembros en donde la formación jurídica no era un requi-

32 ANDREws argumenta que, contrario a la concepción predominante, la Constitución de 1836 no fue la creación de una minoría centralista en el Congreso, sino que fue producto de un debate de casi cinco años previos. ANDrEws, C., «El debate político de la década de 1830 y los orígenes de las siete leyes», en Noriega, C. y SAlmerón, A. (coords.), México: Un siglo de Historia constitucional (1808-1917), México, Poder Judicial de la Federación, 2009, pp. 111 y ss.

33 Inter alia RABASA, E., La Constitución y la dictadura, México, Cámara de Diputados, 1999, pp. 7 y 8. También crítica resultaba la postura de VAllarTa, I., El juicio de amparo y el Writ of Habeas Corpus, México, Díaz de León, 1881, p. 31. Carlos María Bustamante llegó a publicar una réplica a varias objeciones. Cfr. Alfonzo, A., «El Supremo Poder Conservador», en Alfonzo, A. y Cruz, O. et al (coords.), Ensayos histórico-jurídicos: México y Michoacán, México, IIJ-UNAM, 2006, pp. 29-31.

34 Rivera, M., «De Apatzingán a Kelsen: tras las sombras de la justicia constitucional en México», en Andrews, C. et al, Miradas a la Historia Constitucional de México, México, CIDE, 2015, p. 44.

35 Constant, B., Cours de Politique Constitutionnelle, París, Didier, 1839, pp. 185 y 190. Sobre la idea del poder moderador, de VEGA, P., «El Poder Moderador», Revista de Estudios Políticos, núm. 116, 2002, pp. 7-24.

36 Sieyès, E., Escritos políticos de Sieyès, México, Fondo de Cultura Económica, 1993, pp. 257-269.

37 Noriega, A., Las ideas políticas en las declaraciones de derechos de las Constituciones Políticas de México, México, UNAM, 1984, p. 135. Martínez afirma que sólo existe influencia de Sièyes. Martínez, M., «Sieyès en México: acerca de las fuentes del Supremo Poder Conservador», Revista Jurídica Jalisciense, año 6, núm. 3, 1996, p. 264.

38 Kelsen, H., «La Garantie Juridictionnelle de la Constitution», Revue de Droit Public et de la Science Politique, París, 1928, p. 223. 
sito indispensable, la falta del parámetro constitucional y método jurídico como único en sus resoluciones que tampoco adoptaban la forma de sentencias, sino de decretos. Las Siete Leyes es el primer momento constitucional en México en que se rompe conscientemente con la tríada clásica de la división de poderes.

\subsection{La Constitución de 1857}

Tras la caída de la Constitución de 1836 existió un restablecimiento de la Constitución de 1824 mediante el Acta de Reformas de $1847^{39}$. Este interludio sería corto hasta la promulgación de la Constitución de 1857.

La Constitución de 1857 estableció de forma permanente el federalismo y reiteró la fórmula clásica de la división de poderes que había sido sólo prescindida fugazmente en la Constitución de 1836. Si bien la fórmula y número de poderes guarda identidad con su antecedente de 1824 y su consecuente de 1917, la distribución de funciones entre los poderes clásicos tuvo variaciones considerables.

El Constituyente de 1857 intentó justificar su obra con semejanzas a la Constitución de $1824^{40}$. Estableció un sistema tripartita de división de poderes rígido caracterizado por un presidencialismo atenuado (refrendo ministerial y comparecencia de los Ministros ante el Congreso ${ }^{41}$ ). Este Presidencialismo fue establecido «contra los precedentes, las prácticas, las convicciones, incluso ${ }^{42} »$ y se apartó del modelo norteamericano (ausencia de veto).

Además, estableció un sistema unicameral rompiendo con la herencia bicameralista de su predecesora de 1824, aunado a que configuró un poder ejecutivo supeditado al legislativo en facultades ${ }^{43}$. El Constituyente de 1857 concebía al poder ejecutivo y la concentración de facultades como problemáticas y configuró un texto que previniese estas hipótesis ${ }^{44}$. Galeana recuerda que Comonfort (primer Presidente electo bajo esa Constitución) «justificó el golpe de Estado que encabezó porque la Carta Magna dejaba maniatado al Ejecutivo ${ }^{45} »$. Rabasa denunció con fuerza la debilidad del ejecutivo ${ }^{46}$, argumento con cuya conclusión concuerda Cosío Villegas aun-

39 Pantoja, D., «El diseño constitucional del Ejecutivo en México y sus problemas», Op. Cit., p. 259.

40 Zarco, F., Historia del Congreso Extraordinario Constituyente (1856-1857), México, El Colegio de México, 1956, pp. 769-781.

41 Pantoja, D., «La Constitución de 1857 y su interludio parlamentario», Historia Mexicana, México, vol. 57, núm. 4, abril-junio de 2008, p. 1060.

42 Idém.

43 KNApp, F., «Parliamentary Government and the Mexican Constitution of 1857: A forgotten phase of Mexican Political History», The Hispanic American Historical Review, vol. 33, núm. 1, febrero de 1953, p. 66.

44 Hamnett, B., «The Comonfort Presidency, 1855-1857», Bulletin of Latin American Research, vol. 15, núm. 1, 1996, p. 92.

45 Galeana, P. (coord.), Organización y Funciones del Senado, México, IIJ-UNAM, 2010, p. 3.

46 Rabasa, E., Op. Cit., p. 111. 
que disienta de su metodología ${ }^{47}$. Ante este escenario, el propio Cosío Villegas llegó a plantear que debía surgir la duda de si la Constitución de 1857 había creado un régimen parlamentario ${ }^{48}$.

\subsection{0 años de división de poderes: La Constitución de 1917}

La actual Constitución de 1917 es producto de la revolución mexicana. Su gran innovación fue la constitucionalización de derechos sociales. En lo concerniente a la estructuración, concepción e integración de los poderes, no presentó ideas innovadoras a las ya experimentadas por los Constituyentes de 1824 y $1857^{49}$.

Al igual que sus antecesoras de 1824 y 1857, la Constitución de 1917 optó por un modelo federal. La Constitución de 1917 mantuvo la misma redacción de la fórmula integral de división de poderes en su artículo 49. Constatar el establecimiento de una división de poderes tripartita resulta insuficiente para conocer el control político efectivo entre los poderes. Para ello, se requiere conocer la fórmula de integración y competencias de cada poder ${ }^{50}$. En lo concerniente a la distribución de los poderes, la Constitución de 1917 tomó importantes préstamos conceptuales de sus antecesoras, como el restablecimiento del bicameralismo de la Constitución de 1824.

El Poder Ejecutivo sufrió grandes cambios. La Constitución de 1917 creó un Ejecutivo unipersonal de elección popular y directa que se vio fortalecido considerablemente ${ }^{51}$ con facultades de observaciones (veto) que posibilitaban suspensivamente elevar la mayoría a las 2/3 partes de la Cámara para superarlas. Como herencia de la Revolución, se consagró una prohibición de reelección.

Finalmente, estableció un Poder Judicial encabezado y administrado por una Suprema Corte (art. 97 constitucional), cuyos ministros se elegían en un esquema de coparticipación ${ }^{52}$ entre el Poder Ejecutivo y el Senado.

47 Cosío Villegas, D., La Constitución de 1857 y sus críticos, México, Cámara de Diputados, 2014, p. 81. Un análisis de las reformas propuestas en la época al texto de 1857 en LiRA, A., «Juárez y la reforma de la Constitución», en Zoraida, J. (coord.), Juárez: Historia y Mito, Colegio de México, México, 2010, pp. 158 y ss.

${ }_{48}$ Ibíd. p. 85. Previamente KNAPP, F., Op. Cit., pp. 65. Por su parte, Bulnes sostenía que, a pesar de que el parlamentarismo no estaba expresamente consagrado por la Constitución de 1857, sí podía derivarse de su articulado. Bulnes, F., Juárez y las revoluciones de Ayutla y de Reforma, México, 1905, p. 209.

49 Pantoja, D., «El diseño constitucional del Ejecutivo en México y sus problemas», Op. Cit., p. 271.

50 Carbonell, M. y Salazar, P., División de Poderes y Régimen Presidencial en México, México, IIJUNAM, 2006, p. 21.

51 Opinión de Valadés, D., «El sistema presidencial mexicano. Actualidad y Perspectivas», Boletín Mexicano de Derecho Comparado, México, 2011, núm. 130, p. 289.

52 Arroyo, I., «El nuevo diseño de poderes en el Constituyente Mexicano, 1916-1917: Coaliciones parlamentarias y Poder Judicial», en Rojas, L. y DeEds, S. (eds.), México a la Luz de sus revoluciones: Volúmen 2, México, Colegio de México, 2014, p. 270. 
A pesar de las numerosas reformas, en los primeros 80 años de vida constitucional no hubo modificaciones sustanciales a la división de poderes. Sería hasta 1993 en que tendríamos la primera matización al esquema tripartita en tanto la Constitución comenzó a definir a diversos órganos como «autónomos» o poseedores de «autonomía». En esa línea se dio la autonomía del Banco de México (1993), el Instituto Federal Electoral (1996) y la Comisión Nacional de los Derechos Humanos (1999) sin supeditarlos a alguno de los poderes clásicos o tradicionales ${ }^{53}$. Salazar conocidamente sostuvo que, aparejada a desmontar las llamadas «facultades metaconstitucionales», la aparición de los OCA constituyó una ruta de descentralización del poder al sustraer potestades del Poder Ejecutivo ${ }^{54}$, generando una alteración en los contrapesos de los poderes ${ }^{55}$.

La historia constitucional mexicana muestra que la tríada de poderes ha sido predominante en los textos fundamentales previos a la Constitución de 1917 (a partir de las reformas de 1993). Salvo la Constitución centralista de 1836 el debate se dio en torno a la distribución de funciones y no a la arquitectura numérica de los poderes. ¿Qué son los órganos constitucionales autónomos y por qué han cambiado nuestra forma de concebir al poder?

\section{3. ÓRGANOS CONSTITUCIONALES AUTÓNOMOS Y DIVISIÓN DE PODERES}

\subsection{El surgimiento del concepto de órganos constitucionales autónomos}

El concepto de «órganos constitucionales autónomos» ha sido construido por la doctrina mexicana ${ }^{56}$ para explicar el régimen jurídico de ciertos órganos. Esta terminología expresa no se encuentra presente en nuestra Constitución más que para concederles legitimación activa en la controversia constitucional (art. 105, fracción I).

La categoría se compone de tres palabras: «órgano», «constitucional»y «autónomo». Por tanto, la Constitución establece una naturaleza orgánica en el sujeto, que tenga base en su cariz constitucional y con un grado mayor o menor de autonomía ${ }^{57}$.

53 Ovalle Favela, J., «Las controversias constitucionales y los órganos constitucionales autónomos», Cuestiones Constitucionales, México, núm. 25, 2011, p. 117.

54 Salazar, P., El Poder Ejecutivo en la Constitución Mexicana: del metaconstitucionalismo a la constelación de autonomías, México, FCE, 2017, p. 105.

55 Ibidem., p. 106.

56 En la doctrina latinoamericana hay quien ha utilizado la terminología «órganos constitucionales extrapoderes». Cfr. BAZÁn, V., «El Estado de Derecho como zona de interacción», Revista Iberoamericana de Derecho Procesal Constitucional, México, núm. 11, enero-junio de 2009, p. 60.

57 Una primera aproximación al debatible concepto de autonomía puede verse en Romano, S., «Voz autonomía» en su Fragmentos de un diccionario jurídico, Buenos Aires, Ediciones jurídicas EuropaAmérica, 1964, pp. 37 y ss. Hay diferentes tipos de autonomía (técnica, orgánica, financiera, normativa, 
Carbonell sostiene que un órgano constitucional autónomo debe tener las siguientes características: 1) Ser un órgano creado por el texto constitucional; 2) tener, consecuentemente, una garantía institucional de una competencia también garantizada constitucionalmente; 3) llevar a cabo funciones esenciales en los Estados modernos (característica con la que disentimos) y 4) No encontrarse adscritos a otro órgano o poder, pero que sus actos sean revisables por las instancias jurisdiccionales ${ }^{58}$.

Ugalde plantea una caracterización similar al sostener que deben tener autonomía orgánica y funcional, atribución de una función del Estado (autonomía técnica), facultad auto-normativa, autonomía financiera y presupuestaria y finalmente, mantener relaciones de coordinación con otros órganos ${ }^{59}$. Otros autores han «identificado» una extensísima serie de características que llegan a extremos demasiado específicos como el nombramiento de personas de reconocido prestigio, la toma colegiada de decisiones, la mayor duración de su nombramiento que el del resto de órganos del Estado, comparecencias parlamentarias, etc ${ }^{60}$.

Esta falta de unidad de criterios de identificación han hecho que distintos autores discrepen sobre su número. Así, Ugalde incluía en su listado a la Universidad Nacional Autónoma de México ${ }^{61}$. Caballero y Carbonell consideraban a los Tribunales Agrarios en esta categoría ${ }^{62}$. Pedroza incluyó a las Universidades, la Auditoría Superior de Fiscalización, y hasta a los Estados de la República y Municipios ${ }^{63}$. La Secretaría de la Función Pública tenía dentro de su listado de sujetos obligados a la Universidad Autónoma Metropolitana bajo el rubro de «órganos constitucionales autónomos $^{64} \gg$. El listado del antiguo IFE curiosamente identificaba como OCA a la

de funcionamiento, plena, etc.). ( $C f r$. Ugalde Calderón, F., «Órganos constitucionales autónomos», Revista del Instituto de la Judicatura Federal, México, núm. 29, 2010, p. 258). En la doctrina italiana se ha aludido a categorías similares del «polivalente» concepto de autonomía: política, organizativa, normativa —articulada en estatutaria, reglamentaria y legislativa-, administrativa, tributaria, financiera, etc. VANDELLI, L., «Sovranità e federalismo interno: l'autonomia territoriale all'epoca della crisi», Le Regioni, Padua, núm. 5-6, 2012, p. 851. Finalmente, VANDELLI también apunta que el propio calificativo de «autonomía», puede ser hecho en relación con a) La organización; b) la actividad o c) la relación o garantía de un ámbito de protección de carácter administrativo. Los deslindes del concepto son complicados. Se ha hablado también del «carácter derogatorio» de la autonomía constitucional (capacidad de configuración del régimen público propio del sujeto con un particular acento en la potestad de autoorganización que conlleva, a su vez, a la potestad reglamentaria). Midiri, M., Autonomia costituzionale delle Camere e Potere Giudiziario, Padua, Cedam, 1999, pp. 94 y 95.

58 Carbonell, M., Elementos de Derecho Constitucional, México, Fontamara, 2006, p. 105.

59 Ugalde Calderón, F., Op. Cit., p. 259.

60 Estas son algunas de las 19 características que identifica Pedroza de la Llave, S., «Los órganos constitucionales autónomos en México», en Serna de la Garza, J. y Caballero, J. (eds.), Estado de Derecho y transición jurídica, México, IIJ-UNAM, 2002.

61 Ugalde Calderón, F., Op. Cit., p. 260.

62 Caballero OchoA, J., «Los órganos constitucionales autónomos: más allá de la división de poderes», Anuario de Derecho de la Universidad Iberoamericana, México, núm. 30, 2000, pp. 161-169.

63 Pedroza de la Llave, S., «Los órganos constitucionales autónomos en México», Op. Cit., p. 281 y ss.

64 https://bit.ly/36apDptl (consultado el 04/03/2018).

(C) UNED. Revista de Derecho Politico

N.o 110 , enero-abril 2021, págs. 409-440 
Suprema Corte, Tribunal Electoral del Poder Judicial de la Federación, Tribunales Unitarios de Circuito, Tribunales Colegiados de Circuito, Juzgados de Distrito y Consejo de la Judicatura Federal ${ }^{65}$

Ante este caótico panorama, algunos autores han propuesto que se incorpore directamente a la Constitución una noción de órgano constitucional autónomo ${ }^{66}$ o la inclusión de los órganos constitucionales autónomos dentro del esquema de la división de poderes ${ }^{67}$.

\subsection{De confusiones y equívocos: El equivocado uso de la doctrina mexicana de García Pelayo.}

La doctrina, usualmente fuente de esclarecimiento de problemas conceptuales, en el caso de los OCA ha contribuido más bien a acrecentar la confusión. Una problemática conceptual en la definición de los órganos constitucionales autónomos en el caso mexicano es la continua referencia que se ha hecho al concepto de «órganos constitucionales» tomado de la doctrina española (que a su vez lo ha importado de la doctrina italiana ${ }^{68}$ y alemana $\left.{ }^{69}\right)$. Es decir, se ha querido derivar las características de nuestros órganos constitucionales autónomos ${ }^{70}$ de las señaladas por García Pelayo para el Tribunal Constitucional español ${ }^{71}$ en su «El status del Tribunal Constitucional ${ }^{72}$ en el que se aludía a cuatro características: 1) Configuración inmediata por la Constitución; 2) Función y componente fundamental de la estructura constitucional; 3) Participación en la dirección política del Estado ${ }^{73}$ y 4) Paridad de rango y relaciones de coordinación ${ }^{74} »$.

65 Cfr. https://bit.ly/2xnEPST (última consulta 25/03/2020).

66 Caballero Ochoa, J., Op. Cit., p. 170.

67 Salgado, L. y Salazar, P., Op. Cit., p. 597.

68 Véase Martines, T., Diritto costituzionale, Milán, Giuffrè Editore, 2010, p. 176.

69 Un buen intento de sistematización de esta construcción dialéctica en CARPENTIER, E., La résolution jurisdictionnelle des conflits entre organes constitutionnels, Varenne, Clermont-Ferrand, 2006, pp. 111 y ss.

70 Nótese que ya en 1919 RaBASA había utilizado el concepto de «órganos constitucionales» para explicar la realidad de la Constitución de 1857. RaBasa, E., Op. Cit., p. 108.

71 Carpizo, J., «El ministerio fiscal como órgano constitucional autónomo», Revista de Estudios Políticos, Madrid, núm. 125, 2004, p. 66.

72 García Pelayo, M., «El Status del Tribunal Constitucional», Revista Española de Derecho Constitucional, Madrid, vol. 1, núm. 1, enero-abril de 1981, pp. 13-29.

73 Un requisito que curiosamente LuCAS VERDú ni siquiera menciona, aunque luego pase tácitamente a reconocer como órganos constitucionales exclusivamente al Parlamento, Gobierno y Jefe de Estado. Lucas Verdú, P., Curso de Derecho Político (Vol. II), Madrid, Tecnos, 1977, pp. 172-174.

74 García Pelayo, M., «El Status del Tribunal Constitucional», Op. Cit., pp. 13-29. García RoCA sugiere agregar a estos requisitos la autonomía reglamentaria y organizativa. GARCía RoCA, J., El Conflicto entre órganos constitucionales, Op. Cit., p. 91. 
El concepto de órgano constitucional es distinto al de «órgano constitucional autónomo ${ }^{75} »$. Por ejemplo, en México se ha dicho imprecisamente que García Pelayo estableció las características de los órganos constitucionales autónomos ${ }^{76}$ o que García Pelayo estudió a los «organismos autónomos ${ }^{77}$ ». Ello parte de la confusión de la doctrina nacional sobre los términos «órgano constitucional», «órgano de relevancia constitucional»y «órgano constitucional autónomo». Por ejemplo, citando doctrina española, algunos autores mexicanos han afirmado que la Corona es un órgano de relevancia constitucional en España ${ }^{78}$ o que el Tribunal Constitucional en España es un órgano constitucional autónomo ${ }^{79}$ (un error en ambos casos).

Parte del equívoco puede deberse a la diferencia entre «órgano constitucional» como categoría doctrinal y «órgano constitucional» como una descripción de un órgano que está configurado en la Constitución directamente ${ }^{80}$. Todo órgano que inmediatamente provenga de la Constitución será un «órgano constitucional» en un

75 De hecho, hasta donde sabemos, sólo se ha utilizado la terminología «órgano constitucional autónomo» para designar a los «órganos constitucionales» en un solo manual español (López DíAz, E., Iniciación al Derecho, Madrid, Ediciones Delta, 2006, p. 97). Este uso es sumamente atípico y parece más una excepción curiosa que una importación o contacto entre los dos conceptos.

76 Carbonell, M., «Voz órganos constitucionales autónomos», en Carbonell, M. (coomp.), Diccionario de Derecho Constitucional, México, Porrúa, 2002, p. 433 (CARBonell También afirma que JELLINEK y SANTI ROMANO teorizaron sobre los órganos constitucionales autónomos, pero, como se ha analizado, son conceptos diferentes). Lo propio afirma Salazar, P., Op. Cit., p. 106.

77 Ackerman, J., «Organismos autónomos y la nueva división de poderes en México y América Latina» en Carpizo, J. y Arriaga, C. (coords.), Homenaje al Doctor Emilio. O. Rabasa, México, IIJUNAM, 2010, p. 4. Esta terminología (organismos autónomos) es la que se emplea en el Diario Oficial de la Federación. También la emplea Andrade SÁnchez, E., Derecho Constitucional, México, Oxford, 2008 , p. 295. Recientemente, en 2020, Cárdenas llegó a afirmar que «las nociones de Leibholz o Santi Romano sobre los órganos constitucionales autónomos están rebasadas» a pesar de que éstos no escribieron sobre los OCA. CÁRdenAs, J., «Soberanía popular vs. Órganos Constitucionales Autónomos», en López, M. (coord.), Op. Cit., p. 7. El citado autor parece no entender la distinción conceptual entre «órgano constitucional» y «órgano constitucional autónomo» por su similitud semántica.

78 Cárdenas Gracia, J., Una Constitución para la democracia. Propuestas para un nuevo orden constitucional, México, IIJ-UNAM, 2000, p. 247. Ello es un error. La corona es, de hecho, el órgano constitucional prototípico sobre el cual ROMANO trabajó su construcción doctrinal.

79 Ibídem. p. 253. Es una imprecisión afirmar que el TC es un «órgano constitucional autónomo» (pp. 253 y 255). Más cuando el propio Cárdenas (p. 245) sostiene que los «órganos constitucionales autónomos» son lo mismo que los «órganos de relevancia constitucional». El Tribunal Constitucional español no es un «órgano de relevancia constitucional». Tampoco es acertado acudir a JeLLINEK (Cfr. Jellinek, G., Teoría General del Estado, Buenos Aires, Albatros, 1978, p. 412) porque Jellinek se refería allí a «Staatsorgan» y no a «Verfassungsorgan». GARCÍA PELAYO es consciente de este matiz porque alude a una formulación «implícita» en JELlineK, no directa ( $f f r$. García PELAYo, M., «El estatus del Tribunal Constitucional», Op. Cit., p. 12).

80 Cruz Villalón lo distingue. «La Constitución de 1978 ha creado tres órganos constitucionales nuevos, en el sentido usual de órganos cuya estructura y atribuciones se encuentran regulados en la Constitución misma» (así deslinda entre órgano constitucional en sentido descriptivo y el sentido doctrinal). Cruz Villalón, P., La curiosidad del jurista persa y otros estudios sobre la Constitución, Madrid, Centro de Estudios Políticos y Constitucionales, 1999, p. 91. Mismo uso en Astarloa Villena, F., 
sentido descriptivo-semántico, porque emana de la Constitución. Sin embargo, no todo órgano constitucionalizado es un órgano constitucional en el sentido doctrinal al que aludía García Pelayo ${ }^{8 \mathrm{I}}$.

Así, en el caso de México, frecuentemente se ha querido definir órgano constitucional como categoría descriptiva utilizando la terminología y las categorías propias de los órganos constitucionales en sentido doctrinal. Independientemente del equívoco que puede ser inducido por el nombre, los órganos constitucionales autónomos no son órganos constitucionales, sino órganos constitucionalizados ${ }^{82}$. Si se me permite la licencia, la similitud entre un «órgano constitucional»y un «órgano constitucional autónomo», es la que hay entre una «Carta» y una «Carta Magna». La primera designa a una misiva enviada en correspondencia y la segunda a una Constitución: las palabras se parecen, los conceptos que éstas designan no. En palabras de Carpizo «el órgano constitucional al que se refiere García Pelayo es completamente diverso de un órgano constitucional autónomo ${ }^{83}$ ».

Inclusive, en el caso español, la doctrina ha cuestionado la utilidad de la noción de los órganos constitucionales autónomos ${ }^{84}$. Consideran, en cambio, mucho más «aconsejable tomar en consideración otro concepto: el de órganos inmediatos u órganos de relevancia constitucional ${ }^{85}$ ».

El mismo cuestionamiento está presente en la doctrina italiana. Su utilidad histórica es innegable. El concepto de órganos constitucionales elaborado por SANTI Romano desarrollaba un modelo teórico capaz de explicar por qué el rey no es un órgano titular de la soberanía sino un poder constituido más (órgano constitucional en oposición a órgano soberano $\left.{ }^{86}\right)$. La Corona no era así «el órgano soberano» del Estado, sino un órgano constitucional más cuyas relaciones no se rigen por la «supremazia di un organo rispetto a tutti gli altri, adesso deve essere la giuridica coordinazione». Romano constriñó a la Corona como un «organo, oltre che costituzionale e

«Veinticinco años de defensor del pueblo», Cuadernos Constitucionales de la Cátedra Fadrique Furió Ceriol, núm. 58-59, Valencia, invierno-primavera de 2007, pp. 157-185.

81 Cicconetti lo distingue: «Ad una definizione di tipo formalistico — sono organi costituzionali tutti quelli menzionati dalla Costituzione o da leggi costituzionali- se ne contrapponeva una di tipo sostanziali- sono organi costituzionali quelli che, indipendentemente dalla fonte che li preveda, sono essenziali ai finid ella forme di governo-». CicconetTr, S., Lezioni di Giustizia Costituzionale, Turín, Giappichelli Editore, 2010, p. 99.

82 Así, Chueca afirma «el resto de órganos por los que se me pregunta no son en rigor, según se sabe órganos constitucionales. En unos casos se trata de órganos constitucionalizados (...) lo que no es lo mismo». AA.VV., «Encuesta sobre el control del poder y quienes lo ejercen», Teoría y Realidad Constitucional, Madrid, núm. 31, $1^{\mathrm{er}}$ semestre de 2013, p. 31.

83 Carpizo MaC-Gregor, J., «El ministerio fiscal como órgano constitucional autónomo», $O p$. Cit., p. 66.

84 Díez-Picazo, L. y Vidal Marín, T., «Órganos constitucionales», en Aragón Reyes, M. (dir.), Constitución, Estado constitucional, partidos y elecciones y fuentes del Derecho, Pamplona, Thomson Reuters, 2011, p. 98.

85 Ibíd., pp. 99 y 100.

86 Romano, S., Lo Stato moderno e la sua crisis, Milán, Giuffrè, 1969, p. 123. 
individuale, cioè retto da una sola persona, anche primario, cioè non rappresentativo nè del popolo nè di altro órgano ${ }^{87}{ }$.

En el caso español, quizá el concepto podría haber tenido cierta utilidad para acceder al conflicto entre órganos constitucionales pero la ha perdido por la opción de la LOTC de establecer la legitimación en un listado taxativo (art. 59.3) y no como una categoría abierta ${ }^{88}$.

A diferencia de los OCA, la doctrina de los órganos constitucionales no responde a una arquitectura constitucional sino a un diseño en el plano ideológico. Los órganos constitucionales, como categoría, se mueven en el terreno de las ideas y el debate doctrinal, no en el de la configuración normativa. Su fundamentalidad política ${ }^{89}$ puede oponerse a los órganos constitucionales autónomos en su estructura orgánica. Podríamos sostener que los órganos constitucionales autónomos son administraciones independientes vestidas con los ropajes de un órgano constitucional. La constitucionalización de un órgano no lo convierte en órgano constitucional, por lo menos en la acepción doctrinal. La garantía orgánica y no su función, trascendencia ni visos de dirección política, es lo que configura a un órgano constitucional como autónomo, sin importar su función. Es el armazón y no el contenido lo que, a mi juicio, dotan a un órgano de la categoría constitucional en la acepción mexicana. El concepto de órgano constitucional no debe ser analizado en la discusión de los órganos constitucionales autónomos en el caso mexicano.

\subsection{La definición de la Suprema Corte}

La Suprema Corte en la CC 31/2006 refirió ${ }^{90}$ que los órganos constitucionales autónomos surgen bajo la idea de «equilibrio constitucional». Tales órganos, sostuvo, dejan de concebir a la organización estatal derivada de los tres poderes tradicionales y pretende hacer más eficaz el desarrollo de las actividades encomendadas al Estado mediante una distribución de funciones. En segundo punto, afirmó que los OCA han sido establecidos en los textos constitucionales como una forma de dotarlos de garantías de actuación a independencia orgánica, es decir, en tanto su especialización e importancia social, requerían autonomía de los tres poderes clásicos del Estado. En tercer lugar, la Corte afirmó que la creación de los OCA no destruye la teoría clásica de la división de poderes, pues la independencia de éstos de la tríada clásica de poderes

87 Romano, S., Il Diritto Pubblico italiano, Milán, Giuffrè, 1969, p. 117.

88 Rivera León, M., «El peso del elemento subjetivo en el conflicto entre órganos constitucionales», Revista de Derecho Político, Madrid, núm. 87, mayo-agosto de 2013, p. 297.

89 No es sólo su independencia orgánica lo que hace a un órgano carecer del estatus de «órgano constitucional» sino su capacidad de «caratterizzare la forma di Stato o di governo». MARTines, T., Op. Cit., p. 177.

90 Igualmente, Jurisprudencia P./J. 20/2007, visible en el Semanario Judicial de la Federación y su Gaceta, Tomo XXV, mayo de 2007, p. 1647. 
no significa que no formen parte del Estado mexicano, sino que atienden necesidades de la sociedad en general $^{91}$.

Además de ello, la Suprema Corte fijó cuatro «características esenciales» de los OCA, esto es, en su propia doctrina: a) establecimiento directo por la Constitución Federal; b) mantener relaciones de coordinación con los otros órganos del Estado; c) autonomía e independencia funcional y financiera; y d) atención a funciones primarias $\mathrm{u}$ originarias del Estado que requieran ser eficazmente atendidas en beneficio de la sociedad.

La característica (d) es de naturaleza sustantiva. Presupone, necesariamente, que los OCA realizan funciones que por su naturaleza prioritaria requieren autonomía. Como argumentaré en la sección 3.4 b), a mi juicio, la naturaleza de los OCA es un revestimiento orgánico y no sustantivo, como se explicará más adelante.

De igual forma, recientemente en el AR 1100/2015, la Corte sostuvo que no se han delegado a favor de los OCA la totalidad de facultades de otro cuerpo del Estado, sino que su función parte de un régimen «de cooperación y coordinación» y que cuentan con una garantía institucional. Esto es, que son poseedores de una «una protección constitucional a su autonomía y, en esa medida, se salvaguardan sus características orgánicas y funcionales esenciales; de forma que no podría llegarse al extremo de que un poder público interfiera de manera preponderante o decisiva en las atribuciones de un órgano constitucional autónomo ${ }^{92}$ ».

Por último, en la CC 117/2014933 la Corte sostuvo que México adoptó el modelo del Estado regulador con la creación de ciertos OCA a los que confirió la regulación de cuestiones especializadas específicas sobre la base de disciplinas o racionalidades técnicas. Así, intentó definir las competencias reguladoras de éstos en contraposición a las legislativas (Congreso) y reglamentarias (Ejecutivo ${ }^{94}$ ) como basadas en la premisa de que la autonomía y aptitud técnica de tales órganos los tornan «aptos para producir

91 Esta última defensa de la Corte del esquema de la división de poderes es, en realidad, una respuesta a una crítica inexistente. Las críticas a los OCA no se basan en considerar que éstos no forman parte del Estado, sino del desmembramiento de los poderes clásicos (Ejecutivo, Legislativo y Judicial) a favor de nuevos actores no triádicos.

92 De igual forma, véase la tesis 2a. CLXVI/2017 (10a.), de rubro «Garantía institucional de autonomía. Su aplicación en relación con los órganos constitucionales autónomos», visible en la Gaceta del Semanario Judicial de la Federación, libro 48, Tomo I, noviembre de 2017, p. 603.

93 Véase también la jurisprudencia «Estado regulador. El modelo constitucional lo adopta al crear órganos autónomos en el artículo 28 de la Constitución Política de los Estados Unidos Mexicanos», visible en la Gaceta del Semanario Judicial de la Federación, Libro 26, Tomo I, enero de 2016, p. 339.

94 Aquí Roldán sostiene que la Corte erra la interpretación. A su juicio, «la función regulatoria no depende de la naturaleza orgánica de la cual deriva, sino de la racionalidad de la función independientemente de que sea realizada por órganos constitucionales autónomos o por órganos reguladores coordinados. La diferencia orgánica no implica que la administración pública federal no realice funciones regulatorias, sino que realizándola está sujeta a distintas reglas del juego». RoLDÁn, J. «La autonomía constitucional de los órganos reguladores. Hacia una reconstrucción conceptual», en LóPEZ, M. (coord.), Poderes tradicionales y órganos constitucionales autónomos, México, IIJ-UNAM, 2020, p. 35. 
normas en contextos de diálogos técnicos, de difícil acceso para el proceso legislativo».

\section{HACIA UNA NUEVA DEFINICIÓN DE ÓRGANOS CONSTITUCIONALES AUTÓNOMOS}

\section{1. ¿Órganos autónomos o constitucionalización de administraciones independientes $u$ otras instituciones no mayoritarias?}

El concepto de órgano constitucional autónomo ha dado lugar a múltiples equívocos en la doctrina mexicana. A ello ha contribuido que la mayoría de los análisis han sido realizados por constitucionalistas con un enfoque absoluto en su revestimiento orgánico y no bajo enfoques funcionales.

Dussauge afirma que los debates sobre los órganos constitucionales autónomos padecen tres sesgos. En primer lugar, la imprecisa idea de que los orígenes, desarrollos y configuración de tales órganos son producto exclusivo de los vaivenes políticos/ administrativos mexicanos. En segundo lugar, la excesiva atención puesta en sus aspectos jurídicos, simplemente porque nominalmente se les ha definido como «constitucionalmente autónomos»y, finalmente, la tendencia a mirarlos con suspicacia empleando críticas basadas en concepciones sobre la división de poderes ${ }^{95}$.

El primer aspecto precisado por Dussauge es certero. A pesar de que el fenómeno haya sido estudiado en México a partir de 1993, tenemos estudios de, al menos, cincuenta años previos que ya lo mencionaban (por ejemplo, Herrero ${ }^{96}$ en 1943). Por tanto, ni la existencia de órganos fuera de la tríada de poderes ni tampoco su constitucionalización es un fenómeno privativo del caso mexicano.

La crítica de Dussage sobre la excesiva atención dada a los aspectos constitucionales de los OCA es fundada. Sin embargo, ¿no resulta ello natural? Los estudios realizados por constitucionalistas naturalmente ponen un énfasis en la naturaleza constitucional de los órganos porque es bajo el tamiz del constitucionalismo como podemos estudiarlos. Criticar severamente a los constitucionalistas por centrarse en la naturaleza constitucional de los órganos sería como reprochar al análisis politológico de Dussage la escasa atención que pone sobre la naturaleza constitucional de los órganos en cuestión. Ambas perspectivas son sumamente valiosas y necesarias para ofrecer una visión complementaria de los órganos. Para comprender la realidad constitucional de los OCA en México es necesario tanto conocer su naturaleza orgánica (independientemente del rango legal en que se haya consagrado), estudiar comparativamente su utilidad y analizar los matices de su constitucionalización.

95 Dussauge, M., «Organismos constitucionales autónomos y reforma administrativa en México», en del Carmen, M. y Cejudo, G. (eds.), Trayectorias de reformas administrativas en México: Legados y Conexiones, México, El Colegio de México, 2016, p. 478.

96 Herrero, V., La organización constitucional, México, Colegio de México, 1943, p. 46. 
Dussauge con certeza pone sobre relieve que, independientemente del instrumento normativo en que se les haya dotado de autonomía, los OCA pueden ser catalogados como «instituciones no mayoritarias». Stone y Tatcher definen a las instituciones no mayoritarias como:

«(...) those governmental entities that (a) possess and exercise some grant of specialized public authority, separate from that of other institutions, but (b) are neither directly elected by the people, nor directly managed by elected officials ${ }^{97}{ }$.

La noción citada de instituciones no-mayoritarias resulta más amplia que otros conceptos estudiados por la doctrina como las $«$ Administraciones Independientes ${ }^{98}$; es decir, órganos que forman parte de la Administración Pública gestionando servicios públicos, pero no están sometidas a la supervisión ministerial ${ }^{99}$, teniendo también la posibilidad de ejercer potestades normativas ${ }^{100} \mathrm{u}$ otras competencias de ejecución o gestión administrativa. Por ejemplo, Bilbao ${ }^{101}$ menciona en el caso de España al Consejo de Seguridad Nuclear, Consejo del Ente Público RTVE, Comisión Nacional del Mercado de Valores, Agencia de Protección de Datos, Comisión del Mercado de Telecomunicaciones, etc.

Puede argumentarse que las Administraciones Independientes son una especie de instituciones no mayoritarias. Tales instituciones no mayoritarias retiran diversas funciones de los actores políticos buscando volverlas políticamente asépticas y teóricamente más eficientes. La eficiencia de las instituciones no mayoritarias sobre instituciones al mando de políticos electos ${ }^{102}$ es el principal justificante de su existencia. De igual forma, existen justificaciones procedimentales, es decir, sobre la forma de operación de tales instituciones. Se ha argumentado que su funcionamiento tiende a ser más transparente que el de sus contrapartes gubernamentales y que, a pesar de ello, las Legislaturas siguen teniendo cierto tipo de control a través de su nombramiento o posibilidades de solicitar la comparecencia de sus titulares.

Como corolario, los órganos constitucionales autónomos mexicanos no son una formulación estrictamente mexicana, sino que se enmarcan en una tendencia internacional presente en muchos otros ordenamientos. La novedad ha sido la fascinación

97 Stone Sweet, A. y Thatcher, M., «The Politics of Delegation to Non-Majoritarian Institutions», West European Politics, vol. 25, núm.1, 2002, p. 2.

98 Recordemos que, recientemente, la Suprema Corte llegó a hablar de «Agencias Independientes» (independent agencies) en relación al modelo del Estado regulador de ciertos órganos constitucionales autónomos. Es decir, ha habido un roce conceptual moderado. La mención, empero, fue única. Véase el párrafo 325 de la CC 117/2014, resuelta en 2015.

99 BilbaO, J., Op. Cit. p. 164.

100 En España se dotó de potestad normativa al Banco de España, la Comisión Nacional del Mercado de Valores, la Comisión Nacional de Energía y la Comisión del Mercado de las Telecomunicaciones. En este sentido, García Álvarez, G., «Los poderes normativos de las Administraciones Independientes en el ámbito económico», Revista de Administración Pública, Madrid, núm. 171, septiembre-diciembre de 2006, p. 140.

101 Bilbao, J., Op. Cit, p. 163.

102 Stone Sweet, A. y Thatcher, M., Op. Cit., p. 18. 
con su constitucionalización como sujeto de estudio. ¿Por qué ha ocurrido esta constitucionalización?

\subsection{El cariz de la constitucionalización}

La constitucionalización ha sido el rasgo distintivo que ha llevado a la doctrina constitucional mexicana a estudiar los OCA desde una perspectiva orgánica concreta. Resulta curioso que no existan estudios destinados a explicar este fenómeno. Ello es importante dado que ha habido debates en el derecho comparado sobre el problemático encaje de ciertas autoridades independientes en la arquitectura constitucional ${ }^{103}$.

Para el caso mexicano se pueden, al menos, ofrecer dos respuestas, a saber, 1) la inmersión de los OCA dentro de la dinámica de reforma constitucional mexicana y, en segundo plano, 2) la consagración de estas instituciones desde el plano constitucional como forma de evitar dudas sobre su constitucionalidad y engarce en la división de poderes triádica.

a.1) En primer lugar, podemos señalar que el estatus constitucional puede deberse a la concepción política que prevalece subyacentemente a nuestro modelo constitucional. Bajo esta óptica, la constitucionalización de tales entidades se habría dado dentro de un proceso que políticamente enmarca la dirección nacional dentro del propio texto constitucional, así como también producto de una necesidad continua de remarcación del cambio a través del propio texto. La dinámica de la reforma constitucional mexicana ${ }^{104}$ refleja una tendencia creciente a la inclusión de todo tipo de cambio institucional dentro del propio texto con un gran detallismo ${ }^{105}$. A la fecha (30/03/2020), existen 241 decretos de reforma que han realizado más de 600 cambios individuales al articulado de la Constitución. Solamente 21 de los 136 artículos constitucionales ha permanecido sin reforma, lo que implica que han sido modificados 115 artículos constitucionales, equivalentes al $84.5 \%$ del total de artículos constitucionales. He explicado que esta dinámica hiper-reformista se nutre de una concepción política de la Constitución y del detallismo de las previsiones de su texto.

Ésta es la causa mayoritaria de la constitucionalización de tales órganos. Ha existido un deseo de enfatizar mediante el lienzo constitucional el cambio "políticamente aséptico» que se pretendía al retirar ciertas decisiones de la arena política.

103 BilbaO, J., «Las Agencias Independientes: un análisis desde la perspectiva jurídicoconstitucional», Anuario de la Facultad de Derecho de la Universidad Autónoma de Madrid, Madrid, 1999, p. 163.

104 Analizada, inter alia, por VAladÉs, D., «La Constitución reformadora», en GoNZÁlEZ, L. y Valadés, D. (coords.), El Constitucionalismo Contemporáneo, México, IIJ-UNAM, 2013, p. 23.

105 He remarcado el carácter regulatorio de la Constitución como una de las múltiples causas de su excesiva reforma en Rivera León, M., «Understanding Constitutional Amendments in Mexico», Mexican Law Review, Vol. IX, núm. 2, enero-junio de 2017, pp. 3 y ss. 
a.2) En segundo lugar, podemos señalar que, al menos en Estados Unidos ${ }^{106} y$ España, se ha dado cierto debate acerca de la constitucionalidad de crear administraciones independientes, privando al Gobierno de competencias exclusivas garantizadas constitucionalmente ${ }^{107}$. Es decir, si la Administración Independiente (consejos televisivos o de telecomunicaciones, por ejemplo) fue creada mediante ley «¿Puede el legislador sustraer, sin habilitación constitucional expresa, a la dirección gubernamental ámbitos de la gestión pública? ${ }^{108}$ " y ¿qué ocurre con el control parlamentario sobre estas nuevas administraciones? En ausencia de una base constitucional, éstas son preguntas relevantes.

En Estados Unidos, por ejemplo, se ha buscado la justificación congresual para crear agencias independientes en la «necessary and proper clause» derivada de $\mathrm{McCu}$ lloch v. Maryland ${ }^{109}$. Aun cuando la constitucionalización ha ahorrado este debate en México, resulta poco probable que una potencial inconstitucionalidad sea una causa para el fenómeno constitucionalizador en el caso mexicano.

No es el objeto de este texto el debatir si los órganos constitucionales autónomos cumplen o no con los estándares de eficiencia o los métodos decisorios que fungen teóricamente como sus ejes legitimadores. Su valoración fáctica es un tema ajeno a este estudio centrado en las implicaciones de su estatus constitucional en la concepción de la división de poderes. Ahora bien, si tales órganos se enmarcan en la línea internacional de organismos no mayoritarios (algunos específicamente como Administraciones Independientes) ¿ha habido una implicación sustantiva a su naturaleza por el hecho de su constitucionalización? Es decir, sus funciones, su integración, su operación, la finalidad que persiguen, ¿Algo en ello se ha alterado por haberse reglamentado tales aspectos en el texto constitucional y no una ley secundaria?

Ésta es, probablemente, la pregunta que debiera interesarnos a los constitucionalistas. El funcionamiento de tales autoridades en otros marcos jurídicos ha sido estudiado por los administrativistas incluso bajo enfoques específicos de la teoría del New Public Management. Por tanto, en respuesta al cuestionamiento de Dussauge sobre el excesivo enfoque orgánico, poco podemos aportar los constitucionalistas con nuestros métodos y modelos al estudio de este tópico si no es mediante el análisis estrictamente constitucional de la consagración de tales figuras.

A las preguntas formuladas en párrafos anteriores tentativamente respondo en sentido negativo. Operativamente, no hay una diferencia sustancial en que Adminis-

106 Steele, C. y Bowman, J., «The Constitutionality of Independent Regulatory Agencies under the Necessary and Proper Clause: The Case of the Federal Election Commission», Yale Journal on Regulation, núm. 4, 1989, pp. 363 y ss. De igual forma Lavrijssen, S., «An analysis of the Constitutional Position of the US Independent Agencies», en Caranta, R. (coord.), Independent, Administrative Authorities, Londres, British Institute of International and Comparative Law, 2004.

107 Bilbao, J. M., Op. Cit., p. 174.

108 Rallo Lombarte, A., La Constitucionalidad de las Administraciones Independientes, Madrid, Tecnos, 2002, p. 22.

10917 U.S. (4 Wheat.) 316, 415 (1819). 
traciones Independientes u otro tipo de instituciones no mayoritarias encuentren su consagración en la Constitución y no en una ley secundaria: la diferencia proviene del grado de su garantía y no de su fuente. La dinámica que he explicado con anterioridad, ofrece un recuento bastante preciso de las causas que llevaron a la constitucionalización innecesaria de la mayoría de tales órganos. Quizá en casos puntuales (IFE-INE) las concretas circunstancias políticas ofrecían en la Constitución una garantía ulterior sobre su funcionamiento. Empero, en las demás hipótesis mayoritarias, su consagración no ha sido necesaria en la Constitución ni se ha alterado por ello su naturaleza.

¿Es posible sostener la irrelevancia de la fuente de garantía? ¿No cambia en algo el hecho de que el Instituto Nacional de Transparencia, Acceso a la Información Pública y Datos Personales se encuentre en la Constitución y no una ley reglamentaria? La respuesta es negativa. Instituciones análogas se han previsto en diversos países con garantías de funcionamiento similares. Estas instituciones no son nombradas directamente por el ejecutivo (sea ya con «advise and consent» u otro mecanismo de control), no reciben órdenes directas ni forman parte del esquema jerárquico de la Administración Pública cuya cúspide jerárquica es el titular del Ejecutivo. Ahora bien, los organismos no mayoritarios y concretamente las Administraciones Independientes, como hemos señalado, ya han desatado dudas sobre su encaje en la división de poderes. Tinta se ha derramado para determinar su constitucionalidad o su encaje en una clasificación triádica que no acaba de fenecer. Éste es, si se quiere, el efecto principal de la constitucionalización en México de tales figuras. El debate en otras latitudes sobre si es posible privar al ejecutivo de ciertas funciones para conferírselas a una administración independiente presuntamente apolítica no es mayor que el mexicano sobre la naturaleza de las funciones, pero si menor cuando su visibilidad se hace a través de la Constitución. Se ha hecho, pues, evidente en el caso mexicano la voluntad de fragmentación del Estado en una pléyade de agencias, comisiones, institutos. La clásica unitariedad del ejecutivo se rompe en una multitud de dominios legitimizados por su teórica efectividad como elemento último racionalizador. La misma crítica desbocada que Dussauge afirma se ha volcado injustamente sobre los órganos constitucionales autónomos por su ruptura a la tríada de poderes y su «fragmentación estatal» se ha dado también en otros ordenamientos aún en la ausencia de esta constitucionalización. Nos encontramos, pues, ante fenómenos análogos pero cuyo lienzo plasmacional es distinto.

\subsection{Intento de definición y exclusiones}

Hemos visto las problemáticas de conceptualización de los OCA. ¿Cómo podríamos definirlos adecuadamente? Salazar sostenía que su diversidad funcional, estructural y relaciones con el resto de los poderes dificultaba encontrar características comunes más allá de la atribución directa de una autonomía constitucional y el des- 
empeño de funciones anteriormente realizadas por el ejecutivo ${ }^{110}$. A mi juicio, debemos entender que sólo es posible categorizar a una entidad como «órgano constitucional autónomo» cuando 1) El órgano en cuestión se encuentre previsto en la propia Constitución; 2) el órgano tenga una naturaleza regulatoria, administrativa, de política pública o fiscalizadora; 3) el propio texto le confiera un grado de autonomía y 4) se encuentren fuera de la tríada de poderes.

En primer término (1), resulta evidente la necesidad de la categoría de constitucionalización. La autonomía constitucional de un órgano se encuentra prefijada semánticamente a un contenido constitucional concreto. En segundo lugar (2), la naturaleza de tal órgano se basa en las funciones que éstos deben cumplir. Es decir, los OCA son instituciones no mayoritarias constitucionalizadas y siguen la esencia de su funcionamiento en este respecto. Realizan, por tanto, funciones que prototípicamente son administrativas o regulatorias ${ }^{111}$. Esta característica se robustece porque, históricamente, esta autonomía de órganos se ha dado respecto a funciones realizadas por el Estado. En ese sentido, para considerar a un órgano como OCA debe realizar las funciones sustraídas prototípicamente a estos poderes clásicos (mayormente del Ejecutivo). En ese sentido, los OCA tienen mayormente funciones dotadas de impulso político.

Además (3), sostengo que la Constitución debe otorgarles a tales órganos algún grado de autonomía, sin predeterminar aspectos específicos (qué tipos específicos de autonomía). En el caso mexicano, las continuas reformas constitucionales no permiten construir un criterio sólido sobre las facetas de autonomía cuya concesión resultan indispensables y éstas han sido establecidas casuísticamente. Finalmente, la última característica (4), es su naturaleza atriádica. Un OCA necesariamente debe haberse concebido fuera del esquema clásico trinitario de tres poderes para ser considerado como tal.

Bajo este criterio, en realidad, los únicos órganos constitucionales autónomos en la actualidad ${ }^{112}$ son 1) Instituto Nacional Electoral; 2) Instituto Nacional de Estadística y Geografía; 3) Instituto Nacional de Transparencia, Acceso a la Información y Protección de Datos Personales; 4) Comisión Nacional de los Derechos Humanos; 5) Instituto Federal de Telecomunicaciones; 6) Comisión Federal de Competencia Económica; 7) Fiscalía General de la República; 8) Banco de México y 9) Consejo Nacional de Evaluación de la Política de Desarrollo Social ${ }^{113}$.

110 Salazar, P., Op. Cit., p. 111.

111 Al entablar esta característica, como veremos, se excluyen a instituciones jurisdiccionales del predicativo de OCA a pesar de tener autonomía para su dictado.

112 Es importante recordar que, anteriormente, el Instituto Nacional para la Evaluación de la Educación había sido constituido como un órgano constitucional autónomo hasta el 15/05/2019 en que se reformó la Constitución para suprimirlo y transferir la función a un «organismo público descentralizado» al que, a pesar de habérsele conferido autonomía en ciertos sectores, la calificación de «descentralizado» lo priva de la ubicación fuera de la tríada clásica.

113 Un listado similar es el de RuIz, J., «Los órganos constitucionales autónomos en México: una visión integradora», Cuestiones Constitucionales, México, núm. 37, julio-diciembre de 2017. 
Para la definición de tales órganos, prescindo, por tanto, de categorías de fundamentalidad política o de naturaleza esencial. A mi juicio, en el constitucionalismo mexicano, los OCA no requieren, para tener tal naturaleza, que sus funciones sean esenciales o de importancia última al Estado. Los OCA se caracterizan por su estructura orgánica, no por su función específica. Es el órgano y no la función, la que es caracterizada conceptualmente. La consagración de los OCA ha sido una decisión política, hasta cierto punto arbitraria, sobre lo que amerita o no autonomía. Piénsese en órganos como el INEGI o el extinto INEE. La Corte concuerda en la naturaleza de órgano constitucional autónomo del INEGI y del extinto INEE. ¿Podríamos considerar que la estadística y geografía nacional es una función esencial al Estado cuya fundamentalidad amerite autonomía? ¿Y la evaluación de los profesores? La evaluación magisterial no ha sido conceptualizada como una función esencial del Estado que reclame autonomía y, sin embargo, fue perfectamente posible crear un órgano constitucional autónomo que tuviese tal función.

Piénsese que los órganos reguladores cuya autonomía no ha sido constitucionalizada carecen de la naturaleza de OCA, a pesar de realizar funciones análogas a los órganos reguladores cuya autonomía sí ha sido constitucionalizada como la Comisión Federal de Telecomunicaciones.

Bajo el criterio de la Suprema Corte (esencialidad de la función), debería ser debatible si el INEE llegó a ser un órgano constitucional autónomo porque, a pesar de superar naturalmente las primeras tres gradas (revestimientos orgánicos) es bastante debatible que atendiera «funciones primarias u originarias» del Estado. ¿O acaso la evaluación a los docentes —objeto del INEE — era una función «primaria» u «originaria». La realidad mexicana precisa explicaciones minimalistas de los OCA que partan de la base de que, mientras un órgano tenga las atribuciones orgánicas correctas tendrá la autonomía constitucional correspondiente, con independencia del tipo de función que desempeñe. Piénsese que los órganos reguladores cuya autonomía no ha sido constitucionalizada carecen de la naturaleza de OCA, a pesar de realizar funciones análogas a los órganos reguladores cuya autonomía sí ha sido constitucionalizada como la Comisión Federal de Telecomunicaciones.

No inadvierto que mi definición excluye conscientemente de la definición a cualquier tribunal de tener la naturaleza de órgano constitucional autónomo. Los tribunales carecen per se de impulso político. Son actores prototípicamente «pasivos» (the least dangerous branch). Su función de árbitro imparcial les impide situarse en una categoría cuyos protagonistas ejercen funciones mayoritariamente sustraídas del ejecutivo $^{114}$. Aquellos tribunales que sean calificados como autónomos en el caso mexicano o sustraídos de la tríada de poderes, pueden ser vistos como simples órganos jurisdiccionales con garantías reforzadas.

Ahora bien, como he sostenido con antelación, «bajo esta concepción dudo también de que podamos - y debamos - considerar a los Tribunales Agrarios como

114 Como postuló Salazar, P., Op. Cit., p. 105. 
órganos constitucionales autónomos ${ }^{115} »$. Ello no presupone su ausencia de autonomía en tanto juzgados agrarios, pero obviamente contradicen el iter formacional de los OCA trazados por la Corte y la característica sustantiva ( ¿o es inconcebible pensar que los juzgados agrarios formasen parte del Poder Judicial como, por otro lado, es más sensato en la actualidad?) ${ }^{116}$. Tampoco, en tanto juzgados organizados de forma difusa, satisfacen la categoría orgánica. Son juzgados, no órganos. Una consideración análoga debe realizarse frente a los tribunales de lo contencioso-administrativo ${ }^{117}{ }$. Los Tribunales, sin importar su ubicación, no son órganos constitucionales autónomos, sino expresión de la función judicial con distintos grados de garantía orgánica.

La noción anterior puede tener ciertos problemas al momento de considerar la defensa orgánica a través de las controversias constitucionales. Si no los consideramos OCA ¿cómo defenderán entonces sus competencias constitucionales y su esquema en la división de poderes? Sólo los órganos constitucionales autónomos han recibido legitimación en las controversias constitucionales a nivel federal, como parece indicarlo alguna reciente resolución de la Suprema Corte (RR 28/2015-CA). Además de ello, en la AI 53/2015 y sus acumuladas parece haberse dejado entrever que, a pesar de que, si bien los Institutos Electorales Locales pueden calificarse como órganos constitucionales autónomos, no así los Tribunales Electorales locales (parr. 201) a pesar de no encontrarse orgánicamente dentro de la jerarquía del Poder Judicial. Ello refuerza los postulados que aquí hemos intentado defender en la definición conceptual.

Sin embargo, y a pesar de que la Suprema Corte no haya optado por esta interpretación, creemos que es innecesario considerar a los Tribunales Electorales locales/ Tribunales Administrativos/Tribunales Agrarios como órganos constitucionales autónomos para darles un mecanismo de defensa. En primer lugar, la justicia constitucional local podría, prever su inclusión en controversias constitucionales locales. En segundo lugar, dado el natural planteamiento de conflictos dentro de la entidad federativa (y no frente a poderes federales como refiere el inciso l) de la fracción I del artículo 105) parece más sencillo prever su inclusión a través de la fracción h) del propio artículo 105 constitucional. Es decir, si la fracción h) establece la facultad de resolver conflictos entre «dos poderes de una misma Entidad Federativa» ¿Por qué

115 Como sí los considera, Carbonell, M., «Voz órganos constitucionales autónomos», en Carbonell, M. (coomp.), Diccionario de Derecho Constitucional, México, Porrúa, 2002, p. 435. También les otorgaba esa misma naturaleza Caballero OchoA, J., Op. Cit., pp. 161-169.

116 Por otro lado, me parece coherente que MARTINES omita considerar inclusive a los juzgados militares como órganos constitucionales o como órganos de relevancia constitucional, a pesar de estar específicamente previstos en el artículo 103 de la Constitución italiana, fuera del artículo sobre la magistratura en general. Se argumenta, específicamente que «mentre tutti gli organi costituzionali sono instituiti dalla Costituzione, non tutti gli organi previsti nella Costituzione possono definirsi costituzionali». Martines, T., Op.. Cit., p. 178. Algo similar — teniendo en mente las importantísimas diferencias conceptuales- podemos afirmar en México. La palabra «autonomía» no significa siempre «órgano constitucional autónomo».

117 Rivera León, M., Op. cit, p. 130. 
tenemos que interpretar que los poderes constituyen únicamente los órganos formalmente dentro de la tríada? Tal opción (la terminología genérica «poder») requiere un ejercicio interpretativo menos forzado que primero convertir a todos ellos en órganos constitucionales autónomos y luego romper la restricción de las relaciones intersubjetivas federales expresamente establecidas en el inciso l) de la fracción primera del artículo 105.

Tampoco podemos considerar como OCA a las Universidades ${ }^{118}$. Éstas son centros para la impartición de docencia y el desarrollo de labores de investigación y no cumplen con los estándares para ser reconocidas como OCA ${ }^{119}$. De igual manera, al no reunir los requisitos que he enunciado, tampoco tienen carácter de órgano constitucional autónomo la Auditoría Superior de la Federación, al ser un órgano bajo la adscripción de la Cámara de Diputados y el Consejo de la Judicatura Federal, inscrito en la estructura del Poder Judicial. Tales órganos se encuentran inmersos en las estructuras trinitarias propias de la división clásica.

\section{CONCLUSIONES}

El presente estudio ha realizado una radiografía del principio de la división de poderes en México. A partir de ello, se ha analizado la evolución de la división de poderes en los textos constitucionales mexicanos. Hemos sostenido que, a excepción de la Constitución centralista de 1836, el resto de textos constitucionales realizaron una división triádica del poder, aunque con variaciones notables en la distribución de competencias y funciones entre los poderes clásicos.

La actual Constitución de 1917 retomó fuertemente las ideas de sus predecesoras de 1824 y 1857 para realizar una formulación clásica de la división de poderes con una distribución competencial marcada por el presidencialismo y el federalismo. Fue hasta el año 1993 cuando por vez primera se rompió la concepción trinitaria con la paulatina creación de los OCA. El debate parece haber variado y la Constitución de 1836 no se encuentra sola en su rompimiento de la tríada clásica. No sólo debatimos sobre la «distribución del poder» sino sobre el número de pilares que debe contemplar nuestra arquitectura constitucional. Los órganos constitucionales autónomos en México han mostrado que, actualmente, el debate sobre la división de poderes no es sólo sobre las pinceladas de la distribución de funciones, sino el número de sus depositarios.

Como cierto sector de la doctrina ha señalado, existen sesgos en el estudio sobre los órganos autónomos, particularmente en una concepción puramente nacional de los órganos y su atención en lo que he denominado «el cariz de la constitucionaliza-

118 Ibídem, p. 128. De igual forma Salazar, P., Op. Cit., p. 111.

119 Pedroza incorrectamente le atribuía a éstas el carácter de órganos constitucionales autónomos. Pedroza de la Llave, S., «Los órganos constitucionales autónomos en México», Op. Cit., p. 281 y ss. 
ción». Para superar estas problemáticas conceptuales debe encontrarse una teoría que entienda su naturaleza de instituciones no mayoritarias y, en cierta medida, semejante a las administraciones independientes.

Para definir correctamente a los OCA he ofrecido una propuesta basada en cuatro características: 1) El órgano en cuestión se encuentre previsto en la propia Constitución; 2) tiene una naturaleza regulatoria, administrativa, de política pública o fiscalizadora; 3) el propio texto le confiera un grado de autonomía y 4) se encuentren fuera de la tríada de poderes ${ }^{120}$.

En ese sentido, defino a los OCA a que aludimos en la doctrina mexicana como órganos previstos en la Constitución, a los que ésta asigna algún grado de autonomía y sitúa fuera de la tríada clásica de poderes para que realicen funciones regulatorias, administrativas, de política pública o fiscalizadora.

Los órganos constitucionales autónomos muestran que es innecesario mantener una «obsesión trinitaria». La formulación clásica de la división de poderes no es una fórmula prescriptiva que prohíba encontrar nuevas formas de controlar al poder. Comprender el origen y parámetro comparado de los OCA pueden auxiliarnos a centrar el debate sobre la idoneidad del sistema de contrapesos más que en la naturaleza atriádica de sus detentores. El tratamiento presentado en este artículo intenta superar las viejas problemáticas conceptuales de emplear categorías previas (como la de «órgano constitucional») para explicar fenómenos novedosos. Concebir a los OCA sin componentes de esencialidad política — pero sí entendiendo sus revestimientos orgánicos-, puede ayudarnos a entender que el verdadero debate es su engarce funcional y no su ubicación orgánica. Otros países parecen haber adoptado este enfoque funcional, empleen o no el cariz de la constitucionalización.

La división de poderes en México ha seguido los cauces del constitucionalismo global y no parece que una formulación trinitaria rígida pueda seguir siendo el parámetro para evaluar la organización constitucional. Este trabajo, de clarificación conceptual abona a una concepción de la división de poderes en México comprensiva de sus transformaciones y, sobre todo, consciente de que su evolución y garantía puede residir precisamente en el abandono de la naturaleza triádica que históricamente la caracterizaba $^{121}$.

120 Recientemente, Roldán XOPA sostuvo que «El proceso de autonomización implica órganos que ejercen diversas funciones públicas, a partir de su propia identidad orgánica y de su propia legitimidad funcional. No es ya la ausencia del deber de obediencia a instrucciones de otro órgano, la característica definitoria de las autonomías constitucionales». Concordaríamos con el autor en que la naturaleza «atriádica» de un sujeto no conlleva indefectiblemente a considerarlo como un OCA si no cumple con el resto de requisitos enunciados. XopA, J., «La autonomía constitucional de los órganos reguladores. Hacia una reconstrucción conceptual», en López, M, Op. Cit., p. 30.

121 Análogamente Ackerman, B., Op. Cit., p. 725. 
Title:

Transcending trinitarian formulations: Towards a conceptual Theory of Autonomous Constitutional Organs in the Separation of powers in Mexico

Summary:

1. THE SEPARATION OF POWERS AS A CONSTITUTIONAL CONCEPT. 2. EVOLUTION OF THE SEPARATION OF POWERS IN MEXICAN CONSTITUTIONAL HISTORY. 3. AUTONOMOUS CONSTITUTIONAL ORGANS AND SEPARSTION OF POWERS. 4. TOWARDS A NEW DEFINITION OF AUTONOMOUS CONSTITUTIONAL ORGANS. 5. CONCLUSIONS.

\title{
Resumen:
}

En el presente artículo se realiza un análisis de la evolución de la división de poderes en el constitucionalismo mexicano hasta la consagración de los llamados «órganos constitucionales autónomos» (OCA). Se analiza el origen y concepto de los OCA y las imprecisiones definitorias del préstamo conceptual de la doctrina constitucional mexicana de los «órganos constitucionales» en la doctrina española. Finalmente, se propone una noción propia de los órganos constitucionales autónomos que caracterizándolos como administraciones independientes e instituciones no mayoritarias constitucionalizadas, ofrece lineamientos para su identificación.

\begin{abstract}
:
This article offers an analysis of the evolution of the doctrine of the separation of powers in Mexican constitutionalism towards the creation of the so-called «Constitutional Autonomous Organs» (CAO). It studies the origin and concept of the $\mathrm{CAO}$ and the imprecisions caused by employing the concept of «Constitutional Organs» from the Spanish doctrine to explain the mexican-created concept. Also, a notion of the CAO is proposed, This work characterize them as independent administrations or non-majoritarian institutions which have been constitutionalized given the Mexican context. Finally, the article studies the causes and consequences of its constitutionalization in light of the constitutional doctrine towards its conceptualization.
\end{abstract}

Palabras clave:

División de Poderes, Órganos Constitucionales Autónomos, Órganos Constitucionales.

Key Words:

Separation of powers, Constitutional Autonomous Organs, Constitutional Organs. 
